\title{
Coral calcification responds to seawater acidification: a working hypothesis towards a physiological mechanism
}

\author{
F. Marubini · Christine Ferrier-Pagès · \\ P. Furla $\cdot$ D. Allemand
}

Received: 6 November 2007/Accepted: 19 March 2008/Published online: 3 April 2008

(c) Springer-Verlag 2008

\begin{abstract}
The decrease in the saturation state of seawater, $\Omega$, following seawater acidification, is believed to be the main factor leading to a decrease in the calcification of marine organisms. To provide a physiological explanation for this phenomenon, the effect of seawater acidification was studied on the calcification and photosynthesis of the scleractinian tropical coral Stylophora pistillata. Coral nubbins were incubated for 8 days at three different $\mathrm{pH}(7.6,8.0$, and 8.2). To differentiate between the effects of the various components of the carbonate chemistry $\left(\mathrm{pH}, \mathrm{CO}_{3}^{2-}, \mathrm{HCO}_{3}^{-}, \mathrm{CO}_{2}, \Omega\right)$, tanks were also maintained under similar $\mathrm{pH}$, but with $2-\mathrm{mM}$ $\mathrm{HCO}_{3}^{-}$added to the seawater. The addition of 2-mM bicarbonate significantly increased the photosynthesis in $S$. pistillata, suggesting carbon-limited conditions. Conversely, photosynthesis was insensitive to changes in $\mathrm{pH}$ and $\mathrm{pCO}_{2}$. Seawater acidification decreased coral calcification by ca. 0.1$\mathrm{mg} \mathrm{CaCO}_{3} \mathrm{~g}^{-1} \mathrm{~d}^{-1}$ for a decrease of $0.1 \mathrm{pH}$ units. This correlation suggested that seawater acidification affected coral calcification by decreasing the availability of the $\mathrm{CO}_{3}^{2-}$ substrate for calcification. However, the decrease in coral
\end{abstract}

Communicated by: Guest Editor Dr. Katharina Fabricius.

F. Marubini · C. Ferrier-Pagès $(\varangle) \cdot$ P. Furla $\cdot$ D. Allemand Centre Scientifique de Monaco, Avenue Saint-Martin, 98000 Monaco, Principality of Monaco

e-mail: ferrier@centrescientifique.mc

Present Address:

F. Marubini

Joint Nature Conservation Committee, Dunnet House,

7 Thistle Place, Aberdeen AB10 1UZ, UK

Present Address:

P. Furla

University of Nice Sophia-Antipolis, EA ECOMERS,

BP 71, 06108 Nice Cedex 02, France calcification could also be attributed either to a decrease in extra- or intracellular $\mathrm{pH}$ or to a change in the buffering capacity of the medium, impairing supply of $\mathrm{CO}_{3}^{2-}$ from $\mathrm{HCO}_{3}^{-}$.

Keywords Calcification - Biomineralization · Carbon supply · Calicoblastic cells · Buffering capacity · Saturation state of aragonite

\section{Introduction}

The deposition of the calcium carbonate skeleton by scleractinian corals is a highly organized extracellular process. Skeletogenesis is not merely a product of inorganic precipitation out of a super-saturated solution, rather it is regulated by a process that combines organic matrix and mineral depositions in seasonal to diurnal growth layers (Barnes and Lough 1993; Cuif et al. 1999; Cohen and McConnaughey 2003; Allemand et al. 2004; Cuif and Dauphin 2005; Tambutté et al. 2007). Calcification rate is controlled by the calicoblastic epithelium, which provides the peri-crystalline fluid (i.e., the fluid filling the space between epithelium and skeleton) with all necessary factors for calcification. The calicoblastic epithelium secretes the organic matrix (Johnston 1980; Allemand et al. 1998; Puverel et al. 2005; Tambutté et al. 2007), and transports calcium ions (Tambutté et al. 1996; Marshall 1996) and dissolved inorganic carbon (DIC) (Goreau 1961; Furla et al. 2000). The experimental inhibition of any of these processes has been shown to inhibit calcification (Allemand et al. 2004).

Inorganic precipitation of calcium carbonate was also found to be proportional to $\Omega$, the saturation state of seawater, which is equal to $\left[\mathrm{Ca}^{2+}\right] \times\left[\mathrm{CO}_{3}^{2-}\right] / K$, where $K$ is 
the apparent solubility constant for a particular mineral phase of $\mathrm{CaCO}_{3}$. It is therefore largely assumed that $\Omega$ also controls coral calcification at the organismal level (Smith and Buddemeier 1992; Gattuso et al. 1998; Marubini et al. 2001, 2003; see review Raven et al. 2005). A solution with a low $\Omega$ is not energetically favourable for $\mathrm{CaCO}_{3}$ precipitation (Simkiss 1976), and warrants concern for reef health worldwide because $\Omega$ has already decreased over the last century from 5.3 to 4.4 and will keep on decreasing as atmospheric $\mathrm{pCO}_{2}$ increases (Kleypas et al. 1999, 2005; Orr et al. 2005). Such increase in $\mathrm{pCO}_{2}$ has already led to a decrease in $\mathrm{pH}$ of about $0.1 \mathrm{pH}$ unit during the last century (IPCC 2007), resulting in a decrease in $\left[\mathrm{CO}_{3}^{2-}\right]$ and thus $\Omega$. Numerous laboratory experiments have demonstrated that a decrease in seawater $\Omega$, by manipulating either calcium or DIC concentration, induced a correlative 10-30\% decrease in coral calcification (Gattuso et al. 1998; Leclercq et al. 2002; Marubini et al. 2003; Ohde and Hossain 2004; Schneider and Erez 2006; Fine and Tchernov 2007).

One of the main questions that remains to be answered is how can changes in seawater lead to consistent and significant differences in calcification when the magnitude of these changes is much smaller than the large fluctuations in $\Omega, \mathrm{pH}$, or DIC content and speciation that occur within the coelenteric environment between light and dark conditions (Furla et al. 1998, 2000; Al-Horani et al. 2003)? Indeed Furla et al. (1998) showed that the coelenteric $\mathrm{pH}$ fluctuates from 7.4 at night to 8.9 during the day, i.e., a $\Delta \mathrm{pH}$ far larger than that induced by ocean acidification. Furthermore, while two studies performed in the medium term ( $>1$ week) have shown an enhancement of coral growth after an increase in DIC (Marubini and Thake 1999; Herfort et al. 2008), a different result has been found with experiments made on a scale of a few hours, which showed that coral growth was saturated at $\sim 1$-mM DIC (Furla et al. 2000). A potential explanation for these contrasting results may be differences in the period of incubation in DIC-enriched medium, perhaps inducing acclimatization of corals.

Since a decrease in $\Omega$ is always linked to a decrease in $\mathrm{pH}$ and in $\mathrm{CO}_{3}^{2-}$ as well as an increase in $\mathrm{CO}_{2}$ and $\mathrm{HCO}_{3}^{-}$, it is difficult to decipher which parameter, $\mathrm{CO}_{3}^{2-}, \mathrm{pH}$, or $\mathrm{pCO}_{2}$, is responsible for the observed decrease in calcification. Indeed, decreased $\mathrm{pH}$ can change both the availability of nutrients (especially metals, Zeebe and Wolf-Gladrow 2001), and lead to the acidification of body fluids in marine animals, indirectly affecting their growth; increased $\mathrm{CO}_{2}$ concentrations also alter the level of bicarbonate used both in coral photosynthesis and calcification (Langdon and Atkinson 2005).

By doubling the bicarbonate concentration in seawater, it is possible, however, to dissociate the effects of $\mathrm{pH}$ and $\Omega$. If the decrease in calcification is related to $\Omega$ and not to
$\mathrm{pH}$, corals would be expected to grow faster under high $\Omega$ values. Conversely, if coral physiology and cellular processes are governed by $\mathrm{pH}$, then, corals grown at the same $\mathrm{pH}$ should present the same growth rate, independent of $\Omega$. To test this hypothesis, an 8-day experiment was performed maintaining the branching coral Stylophora pistillata in three different $\mathrm{pH}$ and two concentrations of total DIC for each $\mathrm{pH}$. The effect of the changing seawater chemistry was monitored in both rates of photosynthesis and calcification, since the coupling between these two processes, which depend on the same substrate, $\mathrm{HCO}_{3}^{-}$(see review by Allemand et al. 2004), is well known (McConnaughey and Whelan 1997). If increased $\mathrm{CO}_{2}$ concentrations enhance photosynthesis (Goiran et al. 1996), this would be expected to have an effect on the rates of calcification.

\section{Materials and methods}

Colonies of $S$. pistillata were used in this study because its physiology is well known (Muscatine et al. 1989; Tambutté et al. 1996; Shick et al. 2005; Franklin et al. 2006; Stambler and Shashar 2007; Mass et al. 2007). Colonies were sampled in the Gulf of Aqaba in surface waters and maintained for 5 months under culture conditions. Similar sized tips, hereafter called nubbins $(2.5-\mathrm{cm}$ length for calcification, 1-cm length for photosynthesis), were cut from parent colonies using bone cutters. The nubbins were hung by a nylon thread from a supporting structure above the culture aquaria, and were left to recover and grow in the same conditions as the parent colonies for 2 months prior to the start of the experiment. Nubbins were not fed. On average the tissue had already covered the cut surface within the first 2 weeks. At the start of the experiment, nubbins for calcification weighed on average $1.82 \mathrm{~g}$ ( $\mathrm{min}$ 0.45 , max $3.91 \mathrm{~g}$ ).

Six 20-1 aquaria were used to each hold 11 coral nubbins for calcification, and 5 for photosynthesis. Mediterranean seawater from a depth of $50 \mathrm{~m}$ was pumped directly into each aquarium at a rate of $1,000 \mathrm{ml} \mathrm{min}^{-1}$ and the overflow was drained back to the sea. Each tank was fitted with a temperature controller (ElliWell PC902/T), a sensor and a heater (RENA 500W). Temperature was maintained constant at $26.5 \pm 0.3^{\circ} \mathrm{C}$ (mean $\pm \mathrm{SD}$ ). Light was provided $12 \mathrm{~h} \mathrm{~d}^{-1}$ by two overhead metal halide lamps (OSRAM HIQ-T 400W bulbs). Total photosynthetically available radiation (PAR) was $300 \pm 40 \mu$ mole $\mathrm{m}^{-2} \mathrm{~s}^{-1}$ as measured in situ with an underwater spherical $(4 \pi)$ light meter (LICOR 196SA).

The incoming seawater presented a very constant chemistry during the whole experimental period: salinity $38.3, \mathrm{pH}=7.95$, total Alkalinity $=2,500 \mu \mathrm{eq} \mathrm{kg}{ }^{-1}$, and was used directly for one treatment. All 5 other chemical 
Table 1 Carbonate chemistry for each experimental condition

\begin{tabular}{|c|c|c|c|c|c|c|}
\hline Parameter & BA-7.6 & BA-8.0 & BA- 8.2 & BE-7.6 & BE-8.0 & BE-8.2 \\
\hline $\mathrm{TA}\left(\mu \mathrm{eq} \mathrm{kg}{ }^{-1}\right)$ & $2,314 \pm 22$ & $2,544 \pm 27$ & $2,749 \pm 14$ & $3,905 \pm 138$ & $4,342 \pm 110$ & $4,657 \pm 163$ \\
\hline $\mathrm{pH}_{\mathrm{SW}}$ & $7.58 \pm 0.050$ & $7.97 \pm 0.022$ & $8.19 \pm 0.017$ & $7.56 \pm 0.043$ & $7.95 \pm 0.029$ & $8.16 \pm 0.020$ \\
\hline $\mathrm{TCO}_{2}\left(\mu \mathrm{mol} \mathrm{kg}{ }^{-1}\right)$ & 2,204 & 2,224 & 2,243 & 3,762 & 3,881 & 3,927 \\
\hline $\mathrm{pCO}_{2}(\mu \mathrm{atm})$ & 1,323 & 515 & 293 & 2,367 & 945 & 556 \\
\hline $\mathrm{CO}_{3}^{2-}\left(\mu \mathrm{mol} \mathrm{kg}{ }^{-1}\right)$ & 99.1 & 232.5 & 364.8 & 161.7 & 389.1 & 602.6 \\
\hline $\mathrm{HCO}_{3}^{-}\left(\mu \mathrm{mol} \mathrm{kg}{ }^{-1}\right)$ & 2,069 & 1,978 & 1,870 & 3,537 & 3,466 & 3,310 \\
\hline $\mathrm{CO}_{2}\left(\mu \mathrm{mol} \mathrm{kg}{ }^{-1}\right)$ & 35.5 & 13.8 & 7.9 & 63.5 & 25.3 & 14.9 \\
\hline$\beta\left(\mathrm{mM} \mathrm{pH}\right.$ units $\left.^{-1}\right)$ & $3.090 \times 10^{-4}$ & $1.490 \times 10^{-4}$ & $0.994 \times 10^{-4}$ & $5.43 \times 10^{-4}$ & $2.66 \times 10^{-4}$ & $1.80 \times 10^{-4}$ \\
\hline$\Omega_{\text {aragonite }}$ & 1.54 & 3.62 & 5.68 & 2.52 & 6.06 & 9.39 \\
\hline
\end{tabular}

Total alkalinity $(\mathrm{TA})$ and $\mathrm{pH}$ data are means $( \pm \mathrm{SD})$ over the whole experimental period. The rest are calculated from $\mathrm{TA}$ and $\mathrm{pH}$ using the apparent dissociation constants of Mehrbach et al. (1973) for carbonic acid. The aragonite saturation state was calculated according to Mucci (1983). BA = bicarbonate-ambient, BE: bicarbonate-enriched seawater

treatments (see Table 1) were achieved by continuously dripping the required amounts of $\mathrm{NaHCO}_{3}, \mathrm{HCl}$ or $\mathrm{NaOH}$ into each aquarium with a peristaltic pump from solutions made up daily. Treatments were called BA-7.6, 8.0 and 8.2 for bicarbonate-ambient seawater $(2 \mathrm{mM})$ at the three $\mathrm{pH}$ tested, and BE-7.6, 8.0, and 8.2 for bicarbonate-enriched seawater $(4 \mathrm{mM})$ at the same three pHs. Across the six

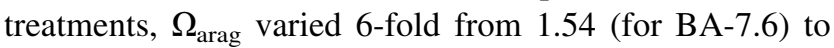
9.39 (for BE-8.2). Total alkalinity was measured potentiometrically with an automated titrator (Metler DL70) and computed using the Gran equation (DOE 1994). Samples were taken three times a week. $\mathrm{pH}$ was measured twice a day on the seawater scale. The components of the carbonate system $\left(\mathrm{pCO}_{2}, \mathrm{HCO}_{3}, \mathrm{CO}_{3}^{2-}\right)$ were calculated from TA and $\mathrm{pH}$ using the apparent dissociation constants of Mehrbach et al. (1973) for carbonic acid. $\mathrm{Ca}^{2+}$ was determined from salinity and temperature. The aragonite saturation state was calculated according to Mucci (1983). Changes in osmolarity, due to addition of $\mathrm{NaHCO}_{3}, \mathrm{HCl}$ or $\mathrm{NaOH}$, were calculated and found to be negligible. The buffering capacity ( $\beta$, expressed as $\mathrm{mM}$. $\mathrm{pH}$ units $^{-1}$ ) of the medium was also considered as the coefficient $\mathrm{dB} / \mathrm{dpH}$, where $\mathrm{dB}$ is the increment of strong base (acid) added, and $\mathrm{dpH}$ the resultant increment of $\mathrm{pH}$. $\beta$ was calculated from the equation $\beta=\ln 10 \cdot \mathrm{Ka} \cdot\left[\mathrm{H}^{+}\right] \cdot \mathrm{TA} /\left(\mathrm{Ka} \cdot\left[\mathrm{H}^{+}\right]\right)^{2}$, where $\mathrm{Ka}$ is the equilibrium constant of the couple $\left(\mathrm{CO}_{2}+\mathrm{H}_{2} \mathrm{O}\right)$ / $\mathrm{HCO}_{3}^{-}(\mathrm{pKa}=6.4)$, TA the total alkalinity, and $\left[\mathrm{H}^{+}\right]$the concentration of $\mathrm{H}^{+}$(Truchot 1987).

Rates of photosynthesis were measured at the end of the 8days of incubation as described in Houlbrèque et al. (2003). Briefly, nubbins were incubated in a 15-ml glass thermostated chamber, filled with the different incubation media, continuously stirred and containing a Strathkelvin $928^{\circledR}$ oxygen electrode (Clark-type electrode). Electrodes were calibrated against air-saturated $(100 \%)$ and sodium dithionite saturated (zero oxygen) incubation media (Houlbrèque et al. 2003). Samples were allowed to acclimate until polyps were expanded. Changes in dissolved oxygen concentrations were monitored on a computer at the culture irradiance and in the dark. Rates were estimated by regressing oxygen data against time, taking into account the seawater volume in the chamber. At the end of the measurements, samples were frozen at $-80^{\circ} \mathrm{C}$ for chlorophyll $a$ determination.

Coral skeletal weight was measured at the beginning and at the end of the 8-day experiment by buoyant weighing (Davies 1989). Corals were handled only by their nylon thread and suspended below a HERAUS precision balance $(0.1 \mathrm{mg})$. The tissue of $S$. pistillata accounted for ca. $1 \pm 0.5 \%$ of the total buoyant weight, and a small correction was therefore made to the results, as in Davies (1989). Growth rate was then calculated on a daily basis and standardized to initial skeletal weight.

The effect of the water chemistry was tested using a two-way ANOVA using StatView software. Results were considered significantly different for values of $P<0.05$.

\section{Results}

$\mathrm{pH}$ treatments were similar in bicarbonate-ambient and bicarbonate-enriched seawater (low $\mathrm{pH}=7.58$ and 7.56; medium $\mathrm{pH}=7.97$ and 7.95 ; high $\mathrm{pH}=8.19$ and 8.16). $\mathrm{pH}$ was maintained constant (maximum variability $=0.05$ ) throughout the experiment. There was no appreciable effect of coral metabolism on seawater chemistry due to the short residence time in the aquaria. Table 1 presents all other parameters of the carbon chemistry in the aquaria.

Protein and chlorophyll $a$ concentrations did not differ between treatments after 8 days (ca. $6 \mathrm{~g}$ and $80 \mathrm{mg} \mathrm{g}^{-1}$, respectively). Figure 1 shows the rates of photosynthesis measured in the experimental tanks. There was no effect of $\mathrm{pH}$. However, rates of photosynthesis were significantly 


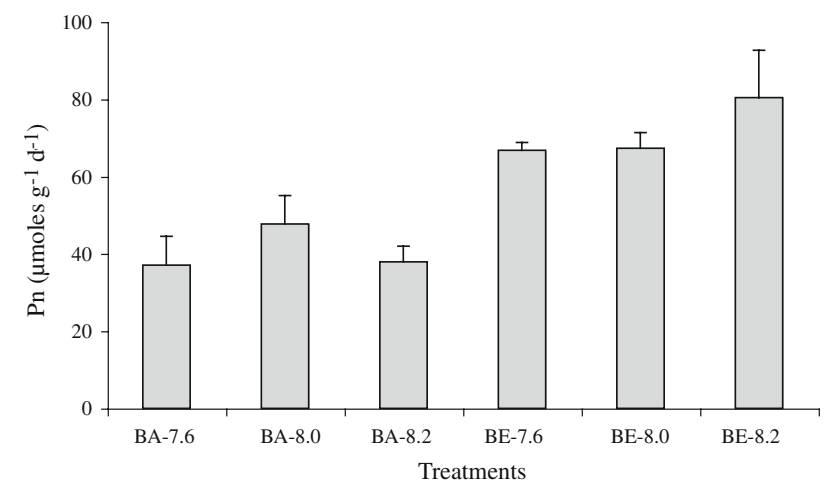

Fig. 1 Effect of seawater acidification on the photosynthetic rate of nubbins of Stylophora pistillata. Photosynthetic rates were measured after 8 days of incubation in bicarbonate-ambient (BA, $2 \mathrm{mM}$ ) and bicarbonate-enriched (BE, $4 \mathrm{mM})$ at 3 different $\mathrm{pH}$ : 7.6, 8.0, and 8.2 (means $\pm \mathrm{SE}$ )

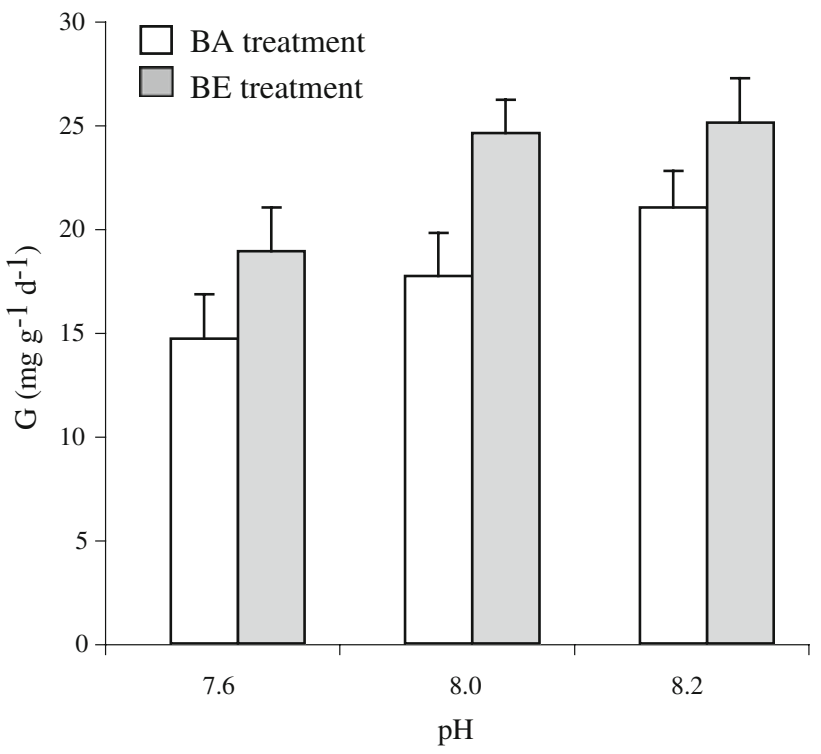

Fig. 2 Effect of seawater acidification on the growth rate of nubbins of Stylophora pistillata. Growth rates (G) were measured after 8 days of incubation in bicarbonate-ambient (BA, $2 \mathrm{mM}$ ) and bicarbonateenriched (BE, $4 \mathrm{mM}$ ) at 3 different $\mathrm{pH}: 7.6,8.0$, and 8.2 (means \pm SE)

$\left(F_{1,50}=46.36, P<0.001\right)$ higher (by ca. $\left.70 \%\right)$ in the bicarbonate-enriched compared to bicarbonate-ambient treatments (Fig. 1).

Coral calcification also varied between treatments (Fig. 2). It was lowest in the BA-7.6 condition $(14.7 \mathrm{mg}$ $\mathrm{CaCO}_{3} \mathrm{~g}^{-1} \mathrm{~d}^{-1}$ ) and maximum in the BE-8 and 8.2 treatments (24.6 and $24.1 \mathrm{mg} \mathrm{CaCO}_{3} \mathrm{~g}^{-1} \mathrm{~d}^{-1}$ ). There was an effect of both $\mathrm{pH}\left(F_{2,60}=12.7, P<0.0001\right)$ and DIC $\left(F_{1,60}=23.5, P<0.0001\right)$ on calcification with no interaction. On average for the same $\mathrm{pH}$, corals in the bicarbonate-enriched seawater grew $27 \%$ faster (range $15-39 \%$ ) than in bicarbonate-ambient seawater. Growth rates were also plotted against the different parameters involved in the DIC equilibrium, i.e., $\mathrm{HCO}_{3}^{-}, \mathrm{CO}_{3}^{2-}, \mathrm{CO}_{2}$ and $\mathrm{pH}$ (Fig. 3; Table 2). For $\mathrm{CO}_{3}^{2-}$ or $\Omega_{\text {arag }}$ there was no significant relationship with growth rate for the data of the separate treatments (bicarbonate-ambient or bicarbonateenriched) but using all data points, there was a positive relationship in both cases (Table 2 , Fig. 3d, e) which tended towards an asymptote as $\mathrm{CO}_{3}^{2-}$ or $\Omega$ arag increased. For all other parameters except $\mathrm{HCO}_{3}^{-}$, growth was linearly correlated for each treatment separately (Table 2, Fig. 3a-c and $f$ ).

\section{Discussion}

The present study investigated the medium term (1-week incubation) effect of seawater acidification on calcification and photosynthesis of the branched coral, S. pistillata. Since acidification alters DIC equilibrium, experiments were performed at normal and double concentrations of $\left[\mathrm{HCO}_{3}^{-}\right]$to discriminate between a $\mathrm{pH}$ or $\Omega\left(\right.$ or $\mathrm{CO}_{3}^{2-}$ ) effect on calcification.

\section{Effect of DIC concentration on photosynthesis}

The results show that the addition of $2-\mathrm{mM}$ bicarbonate in the medium doubled the photosynthesis in S. pistillata, suggesting carbon-limited conditions in this experiment. This is in agreement with the observations of Weis (1993), who demonstrated a bell-shape dependence of the net photosynthetic rate for the sea anemone Aiptasia pulchella on DIC concentrations, with maximal rates obtained at ca. 5-mM DIC. A similar carbon-limitation has also been shown for the corals Porites porites and Acropora sp. with an optimal concentration of 6-mM DIC (Herfort et al. 2008). Flow experiments or stable isotope measurements using corals have also suggested carbon-limitation for photosynthesis (Dennison and Barnes 1988; Muscatine et al. 1989; Lesser et al. 1994; Kühl et al. 1995), but these findings contrast with numerous other observations. Burris et al. (1983) and Schneider and Erez (2006) failed to enhance the rates of photosynthesis of $S$. pistillata and Acropora eurystoma by the addition of bicarbonate, up to concentrations of ca. 4.3 and $2.7 \mathrm{mM}$, respectively. Goiran et al. (1996) also demonstrated that the photosynthesis of Galaxea fascicularis was saturated at around 1.5-mM bicarbonate, either at constant $\mathrm{pH}$ or $\mathrm{pCO}_{2}$. Finally, zooxanthellae photosynthesis did not change with a change in $\mathrm{CO}_{2}$ and $\mathrm{pH}$ (Leclercq et al. 2002; Langdon et al. 2003). The differences in these studies may be a consequence of the different incubation lengths used. Indeed, all the experiments on corals showing no DIC enhancement of photosynthesis were conducted on a rather short time scale (generally a few hours), while in the present experiment, 
Fig. 3 Growth rate $(\mathrm{G})$ of nubbins of Stylophora pistillata as a function of (a) $\mathrm{HCO}_{3}^{-}$, (b) dissolved $\mathrm{CO}_{2}$, (c) $\mathrm{pH},(\mathbf{d})$ $\mathrm{CO}_{3}^{2-}$, (e) $\Omega$, and (f) $\beta$ (means $\pm \mathrm{SE}$ ). Experiments were carried out in bicarbonateambient (black symbols) or bicarbonate-enriched (white symbols) seawater
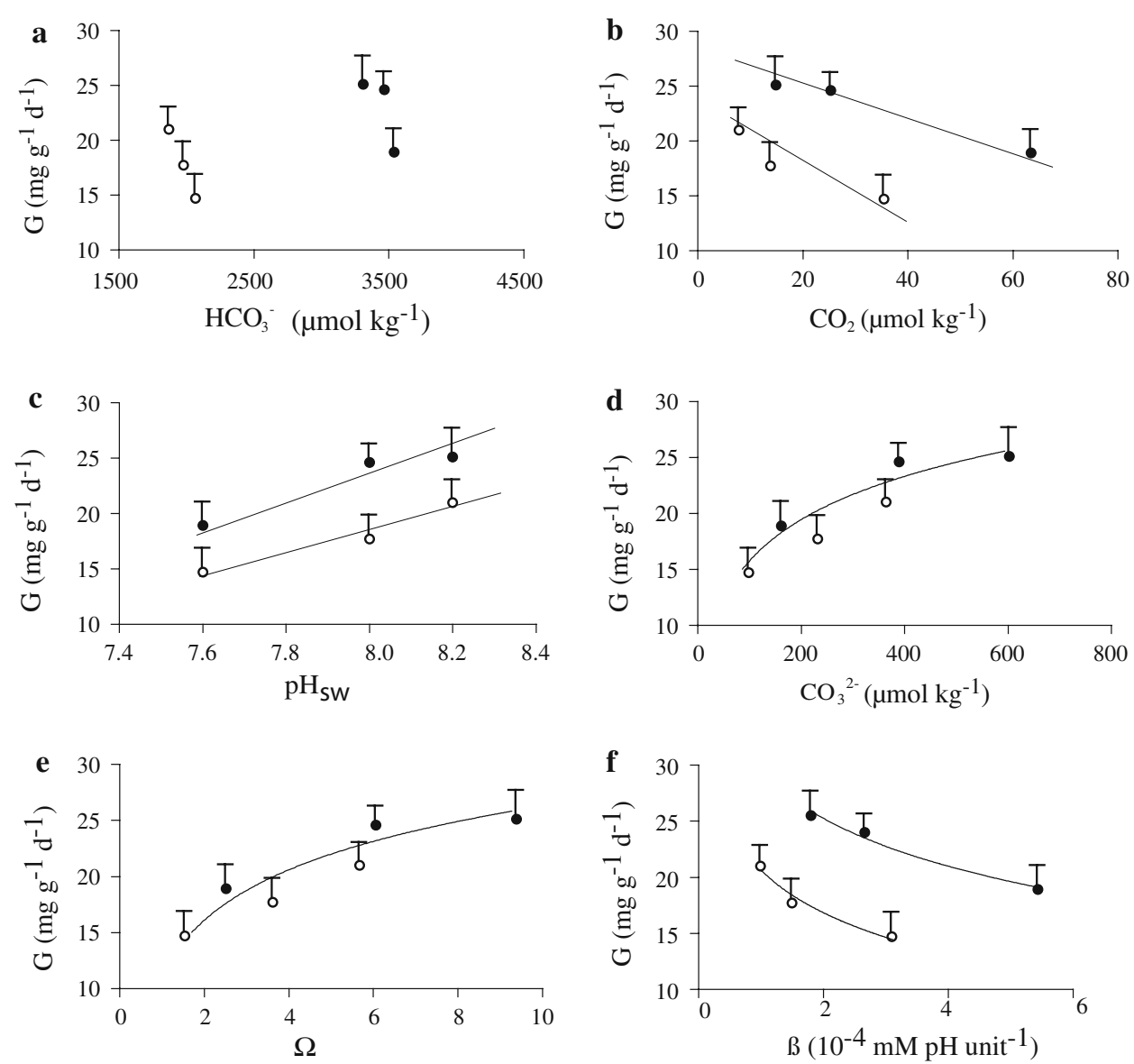

Table 2 Statistical models testing the shape and significance of the relationships of growth $(\mathrm{G})$ to water parameters and their interactions (as shown in Fig. 3)

\begin{tabular}{|c|c|c|}
\hline Relationship & Equation & $R^{2}$ \\
\hline \multicolumn{3}{|c|}{$G$ versus $\mathrm{CO}_{2}$ concentrations } \\
\hline $\begin{array}{l}\text { Bicarbonate- } \\
\text { ambient }\end{array}$ & $y=-0.204 x+21.69$ & $0.89(P=0.006)$ \\
\hline $\begin{array}{l}\text { Bicarbonate- } \\
\text { enriched }\end{array}$ & $y=-0.133 x+27.48$ & $\begin{array}{l}0.99 \\
\quad(P=<0.001)\end{array}$ \\
\hline \multicolumn{3}{|l|}{$G$ versus $p H$} \\
\hline $\begin{array}{l}\text { Bicarbonate- } \\
\text { ambient }\end{array}$ & $y=10.071 x-62.10$ & $0.94(P=0.003)$ \\
\hline $\begin{array}{l}\text { Bicarbonate- } \\
\text { enriched }\end{array}$ & $y=10.893 x-63.55$ & $\begin{array}{l}0.96 \\
\quad(P=<0.001)\end{array}$ \\
\hline \multicolumn{3}{|c|}{$G$ versus $\mathrm{CO}_{3}^{-}$concentrations } \\
\hline $\begin{array}{l}\text { All points } \\
G \text { versus } \Omega\end{array}$ & $y=5.744 \ln (x)-11.64$ & $0.87(P<0.001)$ \\
\hline $\begin{array}{l}\text { All points } \\
G \text { versus } \beta\end{array}$ & $y=5.739 \ln (x)-12.28$ & $0.87(P<0.001)$ \\
\hline $\begin{array}{l}\text { Bicarbonate- } \\
\text { ambient }\end{array}$ & $\begin{array}{l}y=-5.381 \ln (x)- \\
29.05\end{array}$ & $0.96(P=0.002)$ \\
\hline $\begin{array}{l}\text { Bicarbonate- } \\
\text { enriched }\end{array}$ & $\begin{array}{l}y=-6.122 \ln (x)- \\
26.92\end{array}$ & $0.98(P=0.001)$ \\
\hline
\end{tabular}

corals were maintained for more than 1 week in the enriched DIC medium. The longer term increased availability of the substrate may have led to an up-regulation of either carbon transport mechanisms or of the photosynthetic system.

The present results also demonstrate that photosynthesis was insensitive to $\mathrm{pH}$ and $\mathrm{pCO}_{2}$. Indeed for a given DIC concentration, $\mathrm{pH}$ and $\mathrm{CO}_{2}$ had no significant effect on the rates of net photosynthesis, although this $\mathrm{pH}$ decreased by up to 0.6 units, while $\left[\mathrm{CO}_{2}\right]$ increased by $27.6 \mu \mathrm{M}$ in bicarbonate-ambient seawater and by $48.6 \mu \mathrm{M}$ in bicarbonate-enriched seawater (i.e., ca. 4.5-fold increase in $\mathrm{CO}_{2}$ concentration). The lack of $\mathrm{pH}$ effect on photosynthesis was also observed by Goiran et al. (1996) and more recently by Schneider and Erez (2006). However, Goiran et al. (1996) showed that photosynthesis measured in a closed system was enhanced by an increase in dissolved $\mathrm{CO}_{2}$ at constant DIC, suggesting that $\mathrm{CO}_{2}$ supply to photosynthesis may be limiting while total DIC is at saturating concentration. This latter result is however surprising when compared to the present one, where a 4.5-fold increase in dissolved $\mathrm{CO}_{2}$ did not cause any enhancement in $\mathrm{O}_{2}$ production, while a 2-fold increase in total DIC led to almost a 
doubling in $\mathrm{O}_{2}$ production. This suggests that the permeability of zooxanthellae and/or the peri-symbiotic membrane to $\mathrm{CO}_{2}$ is low. Due to this low permeability, the host can easily control the carbon supply to zooxanthellae using membrane carriers.

\section{Effect of change of DIC equilibrium on calcification}

It is assumed that global change-induced ocean acidification is leading to a global decrease in marine calcification (see review by Raven et al. 2005). The results of the present study confirm that seawater acidification leads to a decrease in the growth rate of a tropical coral, S. pistillata. The magnitude of this decrease was about $1-\mathrm{mg} \mathrm{CaCO}_{3}$ $\mathrm{g}^{-1} \mathrm{~d}^{-1}$ for each $0.1 \mathrm{pH}$ unit.

However, the results also showed that a doubling of the seawater bicarbonate concentration lead to an increase in mean growth of $27 \%$, independent of $\mathrm{pH}$ conditions, suggesting that calcification was C-limited. The smallest increase was at a pH of 8.2 (15\% compared to 28 and $39 \%$ at 7.6 and 8, respectively). Marubini and Thake (1999) have previously demonstrated that the addition of $2-\mathrm{mM}$ bicarbonate increased growth rates as well as linear extension rates, and that the response was quick and sustained. More recently, Herfort et al. (2008) also found that the calcification rate of the corals Porites porites and Acropora sp. maintained at $\mathrm{pH} 8.2$ increased with an increase in bicarbonate concentration, up to a total of $6-$ and $8-\mathrm{mM}$ DIC, respectively. These findings contradict the $\mathrm{HCO}_{3}^{-}$dependence curve published by Furla et al. (2000), who showed that calcification was saturated at a concentration of ca. 1-mM $\mathrm{HCO}_{3}^{-}$. Discrepancies between these studies may again be due to the length of the acclimatization process: between $8 \mathrm{~h}$ and 32 days for experiments in which a change in calcification rate was observed (Marubini and Take 1999; Herfort et al. 2008; present study) and $<180 \mathrm{~min}$ when no change was recorded (Furla et al. 2000). A similar up-regulation of proteins involved in C-transport, as suggested for photosynthesis, may explain this result, and implies that corals are able to adapt to change in DIC concentration. Another explanation could be the enhancement of calcification by an enhancement of photosynthetic products. Indeed, both photosynthesis and calcification were significantly increased by the addition of bicarbonate, and it is well known that photosynthesis supplies some precursors of the skeletal organic matrix (see Tambutté et al. 2007 for a review). However, the two mechanisms were not correlated (see below) and there was no proportionality either, since photosynthesis was increased by a factor of ca. 2 , while calcification was only increased by a factor of ca. 1.4.

To determine if the decrease in calcification observed upon acidification was mediated by the direct effect of one particular parameter, relationships were established between skeletal growth and all parameters of the carbon equilibrium. When plotting growth versus the entire set of data for each parameter, a clear relationship was only obtained with $\left[\mathrm{CO}_{3}^{2-}\right]$ and $\Omega_{\text {arag }}$. However, when data were considered separately for each medium (bicarbonateambient and bicarbonate-enriched), linear relationships were observed with all parameters, except bicarbonate (Fig. 3). The lowest concentration of bicarbonate used in the present experiment $(1.87 \mathrm{mM})$ was almost 2-fold higher than the concentration for which Furla et al. (2000) observed a saturation of calcification $(1 \mathrm{mM})$. Since the increase in growth was non-linear, it is possible that bicarbonate ion concentrations above $1 \mathrm{mM}$ are not limiting for calcification, and the supply of carbonate ions for calcification is based upon a simple equilibrium.

Examining the findings that coral growth was correlated with the three parameters $\left(\mathrm{pH}, \mathrm{CO}_{3}^{2-}\right.$ and $\mathrm{CO}_{2}$ ) leads to five hypotheses:

(1) Seawater acidification affects coral calcification through a decrease in photosynthesis. This hypothesis is not supported since calcification and photosynthesis were not correlated (Figs. 1 and 2). Indeed, while calcification was dependent on $\mathrm{CO}_{3}^{2-}$ concentration, photosynthesis was not, suggesting some uncoupling of the processes, as already observed by Schneider and Erez (2006). This uncoupling refutes a possible competition for DIC between calcification and photosynthesis, as suggested by Langdon and Atkinson (2005).

(2) Seawater acidification affects coral calcification through a decrease in carbonate concentration. This hypothesis is supported by the significant correlation between growth and $\mathrm{CO}_{3}^{2-}$ concentration and is in agreement with previous studies performed at the organism (Marubini and Atkinson 1999; Marubini et al. 2001, 2003; Schneider and Erez 2006) and community (Langdon 2000; Langdon et al. 2003; Leclercq et al. 2000) levels. While in most studies, a linear relationship between coral calcification and $\left[\mathrm{CO}_{3}^{2-}\right]$ was observed (Langdon and Atkinson 2005; Schneider and Erez 2006), this relationship was hyperbolic in the present study. This discrepancy is probably related to the different range of carbonate concentrations tested; indeed, the range used by Schneider and Erez (2006), for example, ca. 200 to $<500 \mu \mathrm{M}$ exactly fits within the linear portion of the plot depicted in Fig. 3d. Such a relationship suggests a Michaelis-Menten dependence of coral calcification upon carbonate, or in other words an enzymatic-linked process.

Since increases in $\left[\mathrm{Ca}^{2+}\right]$ or $\left[\mathrm{CO}_{3}^{2-}\right]$ have the same effect on calcification (Gattuso et al. 1998; Langdon 2000), it has been hypothesized that calcification is directly affected by the ion concentration product $\left[\mathrm{Ca}^{2+}\right] \times\left[\mathrm{CO}_{3}^{2-}\right]$ and not by the change in the carbonate chemistry per se (Kleypas et al. 
1999). A good correlation was also observed in this experiment when coral growth was plotted against $\Omega_{\text {arag }}$ (Fig. 3e), the curve being similar to the one obtained with $\mathrm{CO}_{3}^{2-}$ (Fig. 3d). However, the correlation between ambient $\Omega$ and calcification rates is not always obvious (McConnaughey et al. 2000). Indeed, although the coral skeleton is extracellular, it is isolated from seawater by two to four tissue layers (Johnston 1980; Tambutté et al. 2007) and would probably never directly experience seawater $\Omega$ (McConnaughey et al. 2000). How then could changes in carbonate ion concentrations interfere with coral calcification?

If the carbonate ion is the direct carbon source for calcification, it can be supplied either through passive equilibrium between the cœlenteron and the peri-crystalline fluid or by a specific transepithelial transport through a $\mathrm{CO}_{3}^{2-}$ carrier. Although still under debate, the passive transepithelial transport is not supported by the numerous arguments suggesting that the calicoblastic epithelium behaves as a tight epithelium (for review see Cohen and McConnaughey 2003; Allemand et al. 2004). Concerning the $\mathrm{CO}_{3}^{2-}$ carrier hypothesis, no specific $\mathrm{CO}_{3}^{2-}$ carrier has been described until now in the literature, leaving only the possibility that $\mathrm{CO}_{3}^{2-}$ binds to an anion carrier, such as the electrogenic $\mathrm{Na}^{+} / \mathrm{HCO}_{3}^{-}$co-transporters or the sulphate anion transporters in place of $\mathrm{HCO}_{3}^{-}$(see for review Boron 2001; Casey 2006). Furla et al. (2000) were unable to provide evidence that $\mathrm{CO}_{3}^{2-}$ plays a direct role in coral calcification. Moreover, assuming that the intracellular $\mathrm{pH}$ (pHi) of the calicoblastic cells is about 7.4 (a typical value for marine invertebrate cells, Payan et al. 1983), the speciation of DIC would lead to a small amount of $\mathrm{CO}_{3}^{2-}$ compared to $\mathrm{HCO}_{3}^{-}$thus precluding any direct involvement of this ion. The correlation with carbonate does not mean that this ion is directly used for calcification.

(3) Seawater acidification affects coral calcification through an inhibition induced by high $\mathrm{CO}_{2}$ concentrations. Upon hydration, $\mathrm{CO}_{2}$ may lead to acidification of the medium and then alteration of the biological processes. The intracellular $\mathrm{CO}_{2}$ concentration is unknown, but can be estimated taking into account an intracellular bicarbonate concentration of about $3.7 \mathrm{mM}$ (Furla et al. 2000), and a pHi value of 7.4 for marine organisms (Payan et al. 1983). From these assumptions, the intracellular $\mathrm{CO}_{2}$ concentration, calculated using the Henderson-Hasselbalch equation, $\mathrm{pH}=\mathrm{pK}+\log \left[\mathrm{HCO}_{-}\right] /\left[\mathrm{CO}_{2}\right]$ with $\mathrm{pK}=6.1$ (Truchot 1987 ) would be equal to ca. $180 \mu \mathrm{M}$, a value below that reported for vertebrate cells which are in the range 5-15 mM for an extracellular $\mathrm{P}_{\mathrm{CO} 2}$ of about 5\% (Stinner et al. 1994). Therefore a $\mathrm{CO}_{2}$ increase from 10 to $35.5 \mu \mathrm{M}$ (i.e., a $\Delta$ of $25.5 \mu \mathrm{M}$ as in the present study) would decrease pHi by about $0.04 \mathrm{pH}$ units, a value within the range of natural variation experienced by the organism, and therefore insufficient to modify cell physiology as already suggested in plant cells (Bown 1985). Unfortunately, it is impossible to make such calculation for the peri-crystalline fluid, since the $\mathrm{HCO}_{3}^{-}$concentration is unknown, but as this concentration is likely higher than in cells (Allemand et al. 2004), the $\mathrm{pH}$ decrease should be even smaller.

(4) Seawater acidification affects coral calcification through an inhibition induced by decreasing $\mathrm{pH}$. The range of seawater $\mathrm{pH}$, or extracellular $\mathrm{pH}(\mathrm{pHe})$ used in the present study or in most of the above cited literature is large ( $\approx 0.6$ units), but remains in the same range as those observed during a daily cycle in coral tissue (Kühl et al. 1995; Al-Horani et al. 2003) or within the ecosystem (Suzuki et al. 1995), suggesting that coral cells are already adapted to small variations in external $\mathrm{pH}$.

Cells regulate their internal $\mathrm{pH}(\mathrm{pHi})$ by maintaining a difference compared with the extracellular medium (Roos and Boron 1981). Consequently, when extracellular pH varies, $\mathrm{pHi}$ also varies, with the difference depending on the intracellular buffering capacity. In general, internal variations are one half of the external variations (Tufts and Boutilier 1989; Wahl et al. 1996). A similar assumption can be made for transepithelial $\mathrm{pH}$ between cœlenteric cavity and peri-crystalline fluid. In the present study, a $\Delta \mathrm{pHe}$ of ca. $0.6 \mathrm{pH}$ units led to a $30-21 \%$ decrease in calcification at bicarbonate-ambient and bicarbonate-enriched concentration, respectively. Even if this $\Delta \mathrm{pH}$ is lowered by the buffering capacity of the medium, we should expect a significant change, either in the pHi of the calicoblastic cells or of the peri-crystalline fluid, leading to a decrease in the rate of $\mathrm{CO}_{2}$ hydration and $\mathrm{CO}_{3}^{2-}$ formation. Variation of $\mathrm{pHe} / \mathrm{pHi}$ may also affect protonation of amino acid residues such as histidine thus leading to conformational change in protein coupled to a change in their activity (Jiang et al. 2005).

(5) Seawater acidification affects coral calcification indirectly through a change in the buffering capacity of the colenteric space or of the peri-crystalline fluid. The buffering capacity $\left(\beta\right.$, expressed as $\mathrm{mM} \mathrm{pH}$ units $\left.^{-1}\right)$ is defined as:

$\beta=\mathrm{dB} / \mathrm{dpH}$

where $\mathrm{dB}$ is the amount of base (or $\mathrm{H}^{+}$) added to the solution and $\mathrm{dpH}$ is the change in $\mathrm{pH}$ of the solution due to that base (or acid) addition. When $\beta$ increases, $\mathrm{pH}$ change induced by a given amount of base (or acid) decreases. An inverse relationship was found between coral calcification and $\beta$ (Fig. 3f), with slopes and absolute values depending on total DIC. These data therefore suggest that low buffering capacity of the media is associated with high rates of coral calcification. Allemand et al. (2007) reported the same observation in fish otoliths during metabolic acidosis, where a low buffering capacity was reported close to a site of high calcification rate. We may hypothesize that a high $\beta$ may prevent the equilibration between $\mathrm{HCO}_{3}^{-}$and $\mathrm{CO}_{3}^{2-}$, 
since this equilibrium is dependent upon $\mathrm{pH}$, either in the cœlenteron or in the peri-crystalline fluid, thus stopping the carbonate supply to calcification.

In conclusion, this study confirms that global changeinduced seawater acidification may lead to a decrease of tropical coral growth calcification. While the biological mechanism underlying this decrease remains to be elucidated, it is proposed that this effect is either mediated by a decrease in carbonate, in $\mathrm{pH}$, or by an alteration of the internal buffering system leading to a disruption of carbon supply to calcification rather than by a direct effect of $\mathrm{CO}_{2}$ or a change of $\mathrm{HCO}_{3}^{-}$concentration. Results showed that the negative effect of acidification may be counteracted by increasing the bicarbonate concentration of seawater, resulting in an increase in the carbonate concentration.

Acknowledgements We thank Prof. Patrick Payan, Dr Renaud Grover and Dr Sylvie Tambutté for fruitful discussions, Dr. Lydie Herfort for giving us a submitted paper, and Cécile Richard for technical assistance. This study was conducted as part of the Centre Scientifique de Monaco research program, funded by the Government of the Principality of Monaco. FM and PF were supported by a grant from the Scientific Center of Monaco.

\section{References}

Al-Horani FA, Al-Moghrabi SM, de Beer D (2003) The mechanism of calcification and its relation to photosynthesis and respiration in the scleractinian coral Galaxea fascicularis. Mar Biol 142:419-426

Allemand D, Furla P, Bénazet-Tambutté S (1998) Mechanisms of carbon acquisition for endosymbiont photosynthesis in Anthozoa. Can J Bot 76:925-941

Allemand D, Ferrier-Pagès C, Furla $\mathrm{P}$, Houlbrèque $\mathrm{F}$, Puverel $\mathrm{S}$, Reynaud S, Tambutté É, Tambutté S, Zoccola D (2004) Biomineralisation in reef-building corals: from molecular mechanisms to environmental control. Comptes Rendus Palevol 3:453-467

Allemand D, Mayer-Gostan N, De Pontual H, Boeuf G, Payan P (2007) Fish otholith calcification in relation to endolymph chemistry. In: Baeuerlein E (ed) Handbook of biomineralization, vol 1. Wiley-VCH Verlag GmbH \& Co, Weinheim, pp 291-308

Barnes DJ, Lough JM (1993) On the nature and causes of density banding in massive coral skeletons. J Exp Mar Biol Ecol 167:91-108

Boron WF (2001) Sodium-coupled bicarbonate transporters. J Pancreas $2: 176-181$

Bown AW (1985) $\mathrm{CO}_{2}$ and intracellular $\mathrm{pH}$. Plant Cell Environ 8:459-465

Burris JE, Porter JW, Laing WA (1983) Effects of carbon dioxide concentration on coral photosynthesis. Mar Biol 75:113-116

Cohen AL, McConnaughey TA (2003) Geochemical perspectives on coral mineralization. In: Dove PM, Weiner S, Yoreo JJ (eds) Biomineralization. Rev Mineral Geochem 54:151-187

Casey JR (2006) Why bicarbonate? Biochem Cell Biol 84:930-939

Cuif JP, Dauphin Y (2005) The environment recording unit in corals skeletons - a synthesis of structural and chemical evidences for a biochemically driven, stepping-growth process in fibres. Biogeosciences 2:61-73

Cuif JP, Dauphin Y, Freiwald A, Gautret P, Zibrowius H (1999) Biochemical markers of zooxanthellae symbiosis in soluble matrices of skeleton of 24 Scleractinia species. Comp Biochem Physiol 123(A):269-278

Davies PS (1989) Short-term growth measurements of corals using an accurate buoyant weighting technique. Mar Biol 101:389-395

Dennison WC, Barnes DJ (1988) Effect of water motion on coral photosynthesis and calcification. J Exp Mar Biol Ecol 115:67-77

DOE (1994) Handbook of methods for the analysis of the various parameters of the carbon dioxide system in seawater. ORNL/ CDIAC-74

Fine M, Tchernov D (2007) Scleractinian coral species survive and recover from decalcification. Science 315:1811

Franklin DJ, Cedres C, Hoegh-Guldberg O (2006) Increased mortality and photoinhibition in the symbiotic dinoflagellates of the IndoPacific coral Stylophora pistillata (Esper) after summer bleaching. Mar Biol 149:633-642

Furla P, Bénazet-Tambutté S, Jaubert J, Allemand D (1998) Functional polarity of the tentacle of the sea anemone Anemonia viridis: role in inorganic carbon acquisition. Am J Physiol Regul Integr Comp Physiol 274:R303-R310

Furla P, Galgani I, Durand I, Allemand D (2000) Sources and mechanisms of inorganic carbon transport for coral calcification and photosynthesis. J Exp Biol 203:3445-3457

Gattuso JP, Frankignoulle M, Bourge I, Romaine S, Buddemeier RW (1998) Effect of calcium carbonate saturation of seawater on coral calcification. Global Planet Change 18:37-46

Goiran C, Al-Moghrabi S, Allemand D, Jaubert J (1996) Inorganic carbon uptake for photosynthesis by the symbiotic coral/ dinoflagellate association. I. Photosynthetic performances of symbionts and dependence on sea water bicarbonate. J Exp Mar Biol Ecol 199:207-225

Goreau T (1961) Problèmes de croissance et de dépôt du calcium dans les coraux récifaux/Problems of growth and calcium deposition in reef corals. Endeavour 20:32-39

Herfort L, Thake B, Taubner I (2008) Bicarbonate stimulation of calcification and photosynthesis in two hermatypic corals. J Phycol 44(1):91-98

Houlbrèque F, Tambutté E, Ferrier-Pagès C (2003) Effect of zooplankton availability on the rates of photosynthesis and tissue and skeletal growth in the scleractinian coral Stylophora pistillata. J Exp Mar Biol Ecol 296:145-166

IPCC (2007) Climate change 2007: the physical science basis. Contribution of Working Group I to the fourth assessment report of the Intergovernmental Panel on Climate Change. Cambridge University Press, Cambridge

Jiang C, Rojas A, Wang R Wang X (2005) $\mathrm{CO}_{2}$ central chemosensitivity: why are there so many sensing molecules? Respir Physiol Neurobiol 145:115-126

Johnston IS (1980) The ultrastructure of skeletogenesis in zooxanthellate corals. Int Rev Cytol 67:171-214

Kleypas JA, Buddemeier RW, Archer D, Gattuso JP, Langdon C, Opdyke BN (1999) Geochemical consequences of increased atmospheric carbon dioxide on coral reefs. Science 284:118-120

Kleypas JA, Buddemeier RW, Eakin M, Gattuso J-P, Guinotte J, Hoegh-Guldberg O, Iglesias-Prieto R, Jokiel P, Langdon C, Skirving W, Strong AE (2005) Comments on coral reef calcification and climate change: the effect of ocean warming. Response to McNeil et al. 2004. Geophys Res Lett 32:L08601. doi:10.1029/2004GLO22329

Kühl M, Cohen Y, Dalsgaard T, Jorgensen BB, Revsbech NP (1995) Microenvironment and photosynthesis of zooxanthellae in scleractinian corals studied with microsensors for $\mathrm{O}_{2}, \mathrm{pH}$ and light. Mar Ecol Prog Ser 117:159-172

Langdon C (2000) Review of experimental evidence for effects of $\mathrm{CO}_{2}$ on calcification of reef builders. Proc 9th Int Coral Reef Symp 2:1091-1098 
Langdon C, Atkinson MJ (2005) Effect of elevated $\mathrm{pCO}_{2}$ on photosynthesis and calcification of corals and interactions with seasonal change in temperature, irradiance and nutrient enrichment. J Geophys Res C 110:1-54

Langdon C, Broecker WS, Hammond DE, Glenn E, Fitzsimmons K, Nelson SG, Peng T-H, Hajdas I, Bonani G (2003) Effect of elevated $\mathrm{CO}_{2}$ on the community metabolism of an experimental coral reef. Global Biogeochem Cycles 17(1):11-1-11-14

Leclercq N, Gattuso J-P, Jaubert J (2000) $\mathrm{CO}_{2}$ partial pressure controls the calcification rate of a coral community. Global Change Biol 6:329-334

Leclercq N, Gattuso J-P, Jaubert J (2002) Primary production, respiration, and calcification of a coral reef mesocosm under increased $\mathrm{CO}_{2}$ partial pressure. Limnol Oceanogr 47:558-564

Lesser MP, Weis VM, Patterson MR, Jokiel PL (1994) Effects of morphology and water motion on carbon delivery and productivity in the reef coral, Pocillopora damicornis (Linnaeus): diffusion barriers, inorganic limitation, and biochemical plasticity. J Exp Mar Biol Ecol 178:153-179

Marshall AT (1996) Calcification in hermatypic and ahermatypic corals. Science 271:637-639

Marubini F, Atkinson MJ (1999) Effects of lowered pH and elevated nitrate on coral calcification. Mar Ecol Progr Ser 188:117-121

Marubini F, Thake B (1999) Bicarbonate addition promotes coral growth. Limnol Oceanogr 44:716-720

Marubini F, Barnett H, Langdon C, Atkinson MJ (2001) Dependence of calcification on light and carbonate ion concentration for the hermatypic coral Porites compressa. Mar Ecol Prog Ser 220:153-162

Marubini F, Ferrier-Pagès C, Cuif JP (2003) Suppression of growth scleractinian corals by decreasing ambient carbonate ion concentration: a cross-family comparison. Proc R Soc Lond B 270:179-184

Mass T, Einbinder S, Brokovich E, Shashar N, Vago R, Erez J, Dubinsky Z (2007) Photoacclimation of Stylophora pistillata to light extremes: metabolism and calcification. Mar Ecol Prog Ser 334:93-102

McConnaughey TA, Whelan JF (1997) Calcification generates protons for nutrient and bicarbonate uptake. Earth Sci Rev 42:95-117

McConnaughey TA, Adey WH, Small AM (2000) Community and environmental influences on reef coral calcification. Limnol Oceanogr 45:1667-1671

Mehrbach C, Culberson CH, Hawley JE, Pytkowicz RM (1973) Measurement of the apparent dissociation constants of carbonic acid in seawater at atmospheric pressure. Limnol Oceanogr 18:897-907

Mucci A (1983) The solubility of calcite and aragonite in seawater at various salinities, temperatures, and one atmosphere total pressure. Am J Sci 283:780-799

Muscatine L, Falkowski PG, Dubinski Z, Cook PA, Mc Closkey LR (1989) The effects of external nutrient sources on the population dynamics of zooxanthellae in a reef coral. Proc R Soc Lond B 236:311-324

Ohde S, Hossain MMM (2004) Effect of $\mathrm{CaCO}_{3}$ (aragonite) saturation state of seawater on calcification of Porites coral. Geochem J 38:613-621

Orr JC, Fabry VJ, Aumont O, Bopp L, Doney SC, Feely RA, Gnanadesikan A, Gruber N, Ishida A, Joos F, Key RM, Lindsay K, Maier-Reimer E, Matear R, Monfray P, Mouchet A, Najjar RG, Plattner G-K, Rodgers KB, Sabine CL, Sarmiento JL, Schlitzer R, Slater RD, Totterdell IJ, Weirig M-F, Yamanaka Y,
Yool A (2005) Anthropogenic ocean acidification over the twenty-first century and its impact on calcifying organisms. Nature 437:681-686

Payan P, Girard JP, Ciapa B (1983) Mechanisms regulating intracellular $\mathrm{pH}$ in sea urchin eggs. Dev Biol 100:29-38

Puverel S, Tambutté É, Pereira-Mouries L, Zoccola D, Allemand D, Tambutté S (2005) Soluble organic matrix of two Scleractinian corals: partial and comparative analysis. Comp Biochem Physiol B 141:480-487

Raven J, Caldeira K, Elderfield H, Hoegh-Guldberg O, Liss P, Riebesell U, Shepherd J, Turley C, Watson A (2005) Ocean acidification due to increasing atmospheric carbon dioxide. Policy Document 12/05. Royal Society, London

Roos A, Boron WF (1981) Intracellular pH. Physiol Rev 61:296-434

Schneider K, Erez J (2006) The effect of carbonate chemistry on calcification and photosynthesis in the hermatypic coral Acropora eurystoma. Limnol Oceanogr 51:1284-1293

Shick JM, Ferrier-Pagès C, Grover R, Allemand D (2005) Effects of starvation, ammonium concentration, and photosynthesis on the UV-dependent accumulation of micosporine-like amino acids (MAAs) in the coral Stylophora pistillata. Mar Ecol Prog Ser 295:135-156

Simkiss K (1976) Cellular aspects of calcification. In: Watabe N, Wilbur KM (eds) The mechanisms of mineralization in the invertebrates and plants. University of South Carolina Press, Columbia, pp 1-32

Smith SV, Buddemeier RW (1992) Global change and coral-reef ecosystems. Annu Rev Ecol Syst 23:89-118

Stambler N, Shashar N (2007) Variation in spectral reflectance of the hermatypic corals Stylophora pistillata and Pocillopora damicornis. J Exp Mar Biol Ecol 351:143-149

Stinner JN, Newlon DL, Heisler N (1994) Extracellular and intracellular carbon dioxide concentration as a function of temperature in the toad, Bufo marinus. J Exp Biol 195:345-360

Suzuki A, Nakamori T, Kayanne H (1995) The mechanism of production enhancement in coral reef carbonate systems: model and empirical results. Sediment Geol 99:259-280

Tambutté É, Allemand D, Mueller E, Jaubert J (1996) A compartmental approach to the mechanism of calcification in hermatypic corals. J Exp Biol 199:1029-1041

Tambutté S, Tambutté É, Zoccola D, Allemand D (2007) Organic matrix and biomineralization of scleractinian corals. In: Baeuerlein E (ed) Handbook of biomineralization, vol 1. Wiley-VCH Verlag GmbH \& Co, Weinheim, pp 243-259

Truchot JP (1987) Comparative aspects of extracellular acid-base balance. Zoophysiology vol 20. Springer-Verlag, Berlin

Tufts BL, Boutilier RG (1989) The absence of rapid chloride/ bicarbonate exchange in lamprey erythrocytes; implications for $\mathrm{CO}_{2}$ transport and ion distributions between plasma and erythrocytes in the blood of Petromyzon marinus. J Exp Biol 144:565-576

Wahl ML, Coss RA, Bobyock SB, Leeper DB, Owen CS (1996) Thermotolerance and intracellular $\mathrm{pH}$ on two Chinese hamster cell lines adapted to growth at low pH. J Cell Physiol 166: 438-445

Weis VM (1993) Effect of dissolved inorganic carbon concentration on the photosynthesis of the symbiotic sea anemone Aiptasia pulchella Carlgren: role of carbonic anhydrase. J Exp Mar Biol Ecol 174:209-225

Zeebe RE, Wolf-Gladrow D (2001) $\mathrm{CO}_{2}$ in seawater: Equilibrium, kinetics, isotopes. Elsevier Oceanography Series 65 